\title{
Transformasi fungsi catus patha sebagai lanskap sejarah di Kota Denpasar
}

\author{
Putri Saraswati Aryawan ${ }^{1}$, Naniek Kohdrata ${ }^{1^{*}}$, Rochtri Agung Bawono² \\ 1. Prodi Arsitektur Pertamanan, Fakultas Pertanian, Universitas Udayana, Indonesia 80236 \\ 2. Prodi Arkeologi, Fakultas IImu Budaya, Universitas Udayana, Indonesia 80114 \\ *Email: naniek_kohdrata@unud.ac.id
}

\begin{abstract}
Transformation of catus patha functions as historic landscape in Denpasar city. Denpasar city as the Capital of the province, is the center of development in Bali. The former Denpasar city began as a Puri named Puri Denpasar. The location of Puri Denpasar which is the center of government of the Badung Kingdom is in Catus Patha, where the formation of Denpasar city began. This article examine the changes and functions of Catus Patha Denpasar which developed during the Badung Kingdom until now when Denpasar entered the globalization era. The writing method used is only study from various literature sources related to development of the Catus Patha Denpasar. The results of this study are the application of the catus patha concept during the kingdom era can be said to be the most disciplined while it compared to the next periods. In the kingdom era, philosophical values and functions were still original. Entering the colonial era, the elements of the Catus Patha Denpasar is influence by culture brought from Netherlands. Then entering the globalization era, the Catus Patha concept is lies in its elements which also influence its function. The large number of mixed settlements and catur muka statues indicate that the catus patha concept is not well realized in Denpasar.
\end{abstract}

Keywords: catus patha, Denpasar City, transformation

\section{Pendahuluan}

Kota Denpasar sebagai Ibukota Provinsi Bali merupakan pusat perkembangan ekonomi, pendidikan dan budaya di Bali. Kota Denpasar tumbuh dan berkembang dalam perpaduan budaya akibat kegiatan pariwisata yang melibatkan wisatawan asing dan kebudayaan lokal. Perkembangan menyebabkan terjadinya perubahan baik pada bangunan fisik, fungsi maupun makna yang terkandung pada setiap ruang di Kota Denpasar yang tentunya ikut memberi andil terhadap keberadaan tata kota dan wajah kota sebagai akibat dari interaksi satu sama lain dalam proses perubahan tersebut (Setiada, 2009).

Kota Denpasar terdahulu berawal dari sebuah Puri yang bernama Puri Denpasar. Nama Denpasar sendiri dikenal sejak tahun 1861 ketika bangunan puri atau Istana Raja Badung ditempatkan di sebelah utara sebuah pasar (Den = utara, pasar = pasar) (Widiastuti, 2011). Letak Puri Denpasar yang merupakan bagian sekaligus pusat pemerintahan dari Kerajaan Badung dengan pusat kota berada di sekitar Catus Patha Denpasar. Keberadaan catus patha sebagai pusat Kota Denpasar dipengaruhi oleh faktor kekuasaan pada masa kerajaan, yang ditunjukkan dengan penempatan Puri Agung Denpasar yang merupakan tempat penguasa tertinggi Kerajaan Badung di sebelah timur laut catus patha (Putra, 2009). Jadi dapat dikatakan bahwa awal mula terbentuknya Denpasar terjadi di wilayah catus patha.

Pada masa kerajaan di Bali, catus patha bukan sekedar sebagai simpang empat yang memiliki nilai sakral, namun terkait pula dengan statusnya sebagai pusat ibukota kerajaan. Keberadaan catus patha sebagai pusat ibukota kerajaan ditunjukkan dengan adanya unsur puri, pasar, wantilan, alun-alun serta pempatan yang terletak di empat penjuru mata angin (Putra, 2009). Unsur-unsur tersebut merupakan pewadahan segala aktivitas manusia yang menjadi simbol kehidupan material dan spiritual yang diimplementasikan dalam catus patha dengan aktivitas ritual, politik/pemerintahan, perekonomian, dan kebudayaan. Berdasarkan pernyataan tersebut catus patha sebagai pusat ibukota kerajaan tidak hanya 
berfungsi sebagai pusat pemerintahan tetapi juga berfungsi sebagai pusat perekonomian dan kebudayaan serta pusat magis kerajaan (Mahira, 2014).

Pola Catus Patha dengan unsur-unsur pembentuknya seperti yang telah disebutkan Putra (2009) juga tercermin pada pola Catus Patha yang ada di Denpasar pada masa kerajaan. Namun seiring dengan perkembangan zaman yang menyebabkan terjadinya perubahan sistem kekuasaan serta pemerintahan di Kota Denpasar, keadaan catus patha juga turut mengalami perubahan yang tercermin pada keberadaan unsur-unsur catus patha.

Keadaan Catus Patha Denpasar saat ini tidak lebih dari pusat kekuatan politik, perdagangan dan pertahanan seperti yang diciptakan Kerajaan Badung dan Pemerintah Belanda. Catus Patha Denpasar saat ini tidak lagi berfungsi sebagai pusat negara. Berdasarkan keadaan yang telah disebutkan di atas, maka saat ini fungsi Catus Patha Denpasar menarik untuk dilihat kembali. Dalam tulisan ini, akan dibahas kajian mengenai transformasi fungsi dan makna catus patha di Kota Denpasar serta yang memengaruhi perubahannya. Pendekatan penyelesaian masalah yang digunakan dalam tulisan ini adalah dengan cara kajian pustaka, serta hasil yang diharapkan dari kajian ini adalah adanya gambaran secara deskriptif mengenai transformasi fungsi catus patha Denpasar dari zaman Puri Denpasar hingga zaman Indonesia merdeka.

\section{Metode Penelitian}

Tulisan ini mencoba untuk mengkaji mengenai perubahan makna serta fungsi dari Catus Patha Denpasar yang awalnya berkembang pada masa Kerajaan Badung hingga kini Indonesia merdeka dan memasuki era globalisasi. Metode penelitian ini adalah studi pustaka dengan mengkaji sumber teks berupa tulisan maupun gambar terkait dengan perkembangan Catus Patha Denpasar. Sumber data juga dapat diperoleh dari berbagai pustaka terkait dan berbagai arsip berupa foto maupun tulisan yang memuat keadaan Catus Patha Denpasar serta berbagai elemennya. Subyek tulisan ini adalah keadaan Catus Patha Denpasar saat ini sebagai pintu masuk untuk melihat perubahan serta untuk membandingkan makna ruangruang dalam catus patha yang sesuai berdasarkan makna serta filosofinya dengan perkembangan dan perubahan yang saat ini telah terjadi.

\section{Hasil dan Pembahasan}

\subsection{Makna dan Filosofi Catus Patha}

Istilah catus patha berasal dari dua kata Bahasa Sansekerta yaitu kata catus yang berarti empat dan kata patha yang berarti jalan, sehingga bila dipadukan berarti jalan yang bercabang empat atau simpang empat (Putra, 2009). Konsep catus patha pertama kali berkembang di Kerajaan Majapahit dan dibawa ke Bali kemudian digunakan untuk konsep pembangunan kerajaan Hindu (Munandar, 2011). Pada zaman kerajaan di Bali catus patha bukan hanya sekedar simpang empat atau yang dikenal dengan nama pempatan agung yang memiliki nilai sakral, namun terkait pula dengan statusnya sebagai ibukota kerajaan atau pusat negara. Adapun unsur-unsur yang terkandung dalam catus patha dalam kedudukannya sebagai pusat negara adalah: puri sebagai keraton atau pusat pemerintahan merangkap sebagai tempat tinggal raja; pasar sebagai pusat perdagangan/tempat transaksi; bangunan wantilan sebagai pusat budaya/hiburan khususnya sabung ayam (tajen); serta ruang terbuka umum yang digunakan untuk taman rekreasi masyarakat.

Konsep tentang negara dan tata letak suatu puri dalam catus patha di Bali tertuang dalam Lontar Eka Pretamaning Brahmana Sakti Bujangga, Lontar Batur Kalawasan dan Lontar Catur Bumi, dalam Iontar tersebut dijelaskan orientasi, elemen dan mitos fungsi Puri yang sesuai dengan hubungan makrokosmos (alam) dan mikrokosmos (manusia) (Yudantini \& David, 2015). Secara filosofi, catus patha merupakan pertemuan empat ruas jalan yang menjadi implementasi arah horizontal (kangin-kauh/timur-barat dan kajakelod/utara-selatan/gunung-laut), serta pertemuan antara arah horizontal tersebut dengan arah vertikal (atasbawah/akhasa-pertiwilangit-bumi/purusa-pradhana) dengan titik ruang kosong sebagai simbol dari proses penciptaan dan sumbu magis alam semesta/kosmos (Mahira, 2014). Berdasarkan Lontar Eka Pretamaning Brahmana Sakti, catus patha merupakan simbol pusat dunia. Peletakan puri sebagai pusat kekuasaan ditentukan menurut arah mata angin dari pusat catus patha ini. Pernyataan ini juga didukung juga oleh Lontar Batur Kelawasan yang menyebutkan bahwa posisi puri di timur laut adalah utama, di tenggara adalah buruk karena menurut kepercayaan negara akan hancur (gni rurub), di barat daya adalah baik karena raja akan 
dihormati (kweh bakti), dan di barat laut adalah baik karena raja akan bersifat sosial (dana). Berdasarkan kedua sumber diatas maka dapat disimpulkan bahwa letak pusat pemerintahan ditentukan dari pusat catus patha berdasarkan arah mata angin (Putra, 2009).

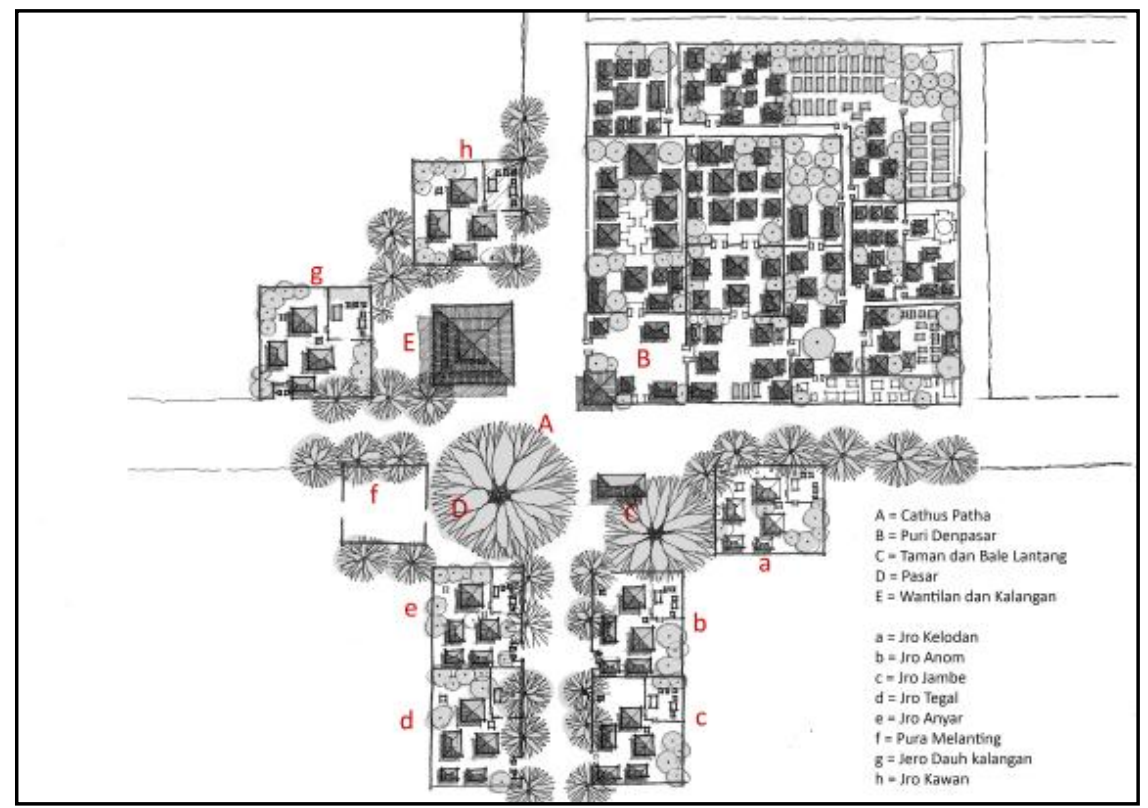

Gambar 1. Elemen-elemen Catus Patha Denpasar pada Masa Pemerintahan Puri Denpasar. (Sumber: Putra, 2018).

Catus patha memiliki bentuk dasar seperti tanda tambah (+) dalam istilah Bali disebut juga dengan tapak dara yang mitologinya terdapat pada Lontar Catur Bumi. Masyarakat Yunani kuno menyebut tapak dara ini dengan istilah gammadion. Tapak dara ini kemudian juga mengilhami koordinat Cartesius dalam matematika dan menjadi dasar swastika. Bila swastika merupakan simbol perputaran alam semesta, maka tapak dara (sumbu salib) merupakan simbol alam semesta. Tapak dara ini juga digunakan sebagai penangkal unruk menghindari malapetaka (Mahira, 2014).

Makna filosofi catus patha bila dikaitkan dengan aktivitas ritual masyarakat Hindu di Bali yang dilaksanakan di catus patha, merupakan simbol dari proses penciptaan dan kehidupan menuju dn berawal dari alam sunya/kosong. Pada titik kosong tersebut terdapat pertemuan antara unsur purusa dan pradana, atau langit-bumi sehingga tercipta kehidupan di alam semesta ini yang terproses secara berulang dengan tujuan kembali kepada Tuhan sebagai Sang Tunggal (Atmaja, 2003).

\subsection{Pengertian Lanskap Sejarah}

Menurut Simonds (1983), lanskap adalah suatu bentang alam dengan karakteristik tertentu, yang dapat dinikmati oleh seluruh indera manusia. Lanskap terdiri atas lanskap alami dan lanskap buatan. Lanskap alami sangat rumit sehingga sangat penting bagi perancang untuk memahami lebih dalam untuk menjaga elemen yang tidak boleh diganggu dan yang tetap dipertahankan pada lanskap. Lanskap buatan merupakan lanskap alami yang mengalami modifikasi yang dilakukan oleh manusia. Dalam Kamus Umum Bahasa Indonesia (2003) yang ditulis oleh W.J.S. Poerwadaraminta menyebutkan bahwa sejarah mengandung tiga pengertian sebagai berikut:

a. Sejarah berarti silsilah atau asal usul.

b. Sejarah berarti kejadian dan peristiwa yang benar-benar terjadi pada masa lampau.

c. Sejarah berarti ilmu, pengetahuan, cerita pelajaran tentang kejadian atau peristiwa yang benar-benar terjadi pada masa lampau.

Lanskap sejarah menurut Nurisjah dan Pramukanto (2001) adalah bagian dari suatu lanskap budaya yang memiliki dimensi waktu di dalamnya. Lanskap sejarah ini dapat mempunyai bukti fisik dari keberadaan manusia di atas bumi ini. Waktu yang tertera dalam suatu lanskap sejarah yang membedakan dengan desain lanskap lainnya, adalah keterkaitan pembentukan essential character dari lanskap ini dari waktu atau periode 
yang lalu yang didasarkan pada sistem periodikal yang khusus (seperti sistem politik, ekonomi dan sosial). Lanskap sejarah memainkan peranan penting dalam mendasari dan membentuk berbagai tradisi budaya, ideologikal dan etnikal satu kelompok masyarakat.

Lanskap sejarah memiliki karakter yang terdiri atas karakter utama kawasan, situs atau tapak tersebut dan hubungan-hubungannya dengan tapak. Dua faktor pembentuk tersebut adalah:

a. Historic/prehistoric feature, yaitu feature yang terletak di atas atau di bawah permukaan tanah (seperti lanskap).

b. Informasi-informasi sejarah yang berhubungan dengan tapak tersebut (seperti cerita rakyat, legenda, atau catatan sejarah proses terjadinya suatu tapak).

Goodchild (1990) mengemukakan bahwa suatu lanskap dikatakan memiliki nilai historis apabila di dalamnya memuat satu atau beberapa kondisi lanskap berikut ini:

a. Merupakan contoh yang menarik dari sebuah tipe lanskap sejarah.

b. Memuat bukti yang menarik untuk dipelajari terkait dengan sejarah tata guna.

c. Lahan, lanskap, taman, atau sikap budaya terhadap lanskap dan taman.

d. Memiliki keterkaitan dengan seseorang, masyarakat atau peristiwa atau peristiwa yang penting dalam sejarah.

e. Memiliki nilai-nilai sejarah dengan bangunan atau monumen bersejarah.

\subsection{Transformasi Catus Patha Kota Denpasar}

Penerapan konsep catus patha pada masa kerajaan dapat dikatakan sebagai penerapan yang paling taat dan disiplin dibandingkan dengan masa-masa selanjutnya. Kaidah-kaidah konsep dan makna dari catus patha sangat diperhatikan pada saat pembangunan maupun dalam pengaturan tata ruang di Kerajaan di Bali. Setelah zaman kerajaan atau pada masa pemerintahan kolonial Belanda walaupun tetap memegang beberapa kaidah dari catus patha, namun tidak ada pembangunan puri baru sebagai lokasi untuk mengontrol pemerintahan wilayah, hal ini kemudian berlanjut sampai zaman kemerdekaan. Pembahasan mengenai perkembangan Catus Patha Kota Denpasar dibagi ke dalam tiga periode yakni sebagai berikut:

\subsubsection{Periode zaman kekuasaan Puri Denpasar}

Perkembangan konsep catus patha pada negara kerajaan di Denpasar diawali dari berkuasanya Kerajaan Badung yang berpusat di Puri Denpasar. Pada prinsipnya, perkembangan Kota Denpasar dimulai dari lima titik utama yaitu: Puri Denpasar sebagai pusat Kerajaan Badung, Puri Pemecutan yang merupakan tempat tinggal keluarga sulung Raja Badung yaitu I Gusti Ngurah Gde Pemecutan, Puri Kesiman yang merupakan tempat tinggal salah satu putra Raja Badung, Puri Jro Kuta, dan yang terakhir adalah Puri Satria.

Pada zaman kerajaan morfologi Kota Denpasar terbentuk dari konsep Desa Adat. Konsep ini menempatkan pempatan agung atau dalam hal ini adalah catus patha sebagai pusatnya. Catus Patha Denpasar tersusun dari elemen-elemen antara lain: puri dan jero, wantilan, pura, pasar, alun-alun, dan pohon beringin. Berdasarkan morfologi tersebut, letak Puri Denpasar berada di timur laut catus patha, di sebelah tenggara catus patha terdapat alun-alun, kemudian di arah barat daya catus patha terdapat pasar, serta di arah barat daya catus patha dibangun wantilan. Unsur-unsur dari catus patha dan pempatan agung inilah yang sampai saat ini menjadi dasar pembentukan fisik Kota Denpasar. Pusat kota pada periode ini mencerminkan spirit sertai energi spiritual Kerajaan Badung selain fungsinya sebagai pusat pemerintahan, perdagangan dan budaya (Widiastuti, 2011). 


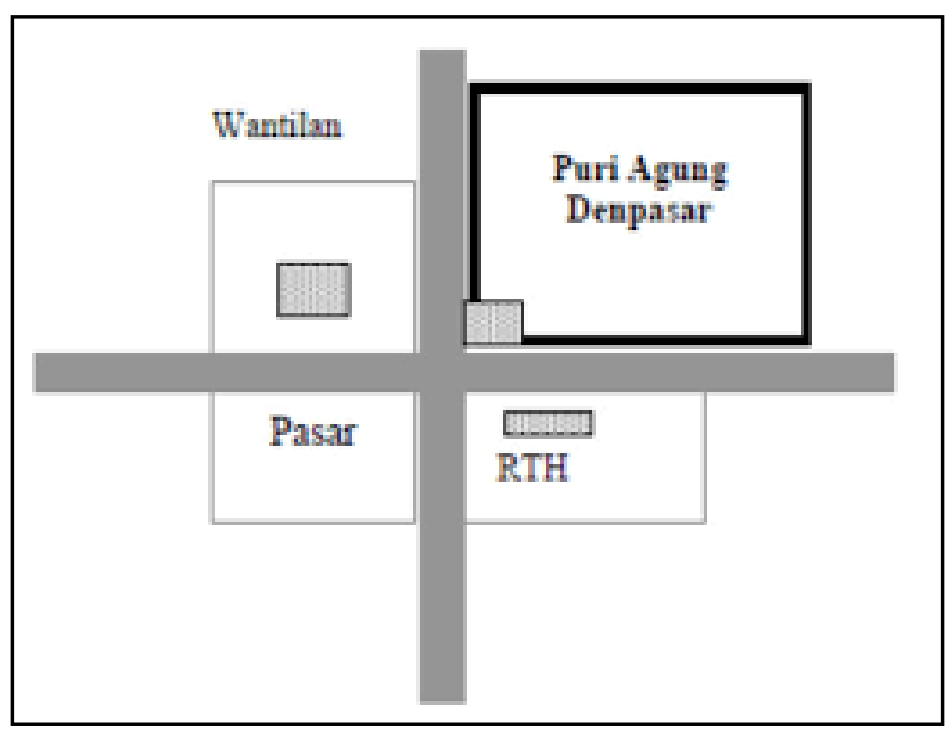

Gambar 2. Denah Catus Patha Denpasar pada Masa Pemerintahan Puri Denpasar.

(Sumber: Dharma \& Weko, 2017)

Struktur yang serupa juga ditunjukkan pada morfologi Pempatan Agung Pemecutan. Keterkaitan hubungan antara Puri Denpasar dan Pemecutan ditunjukkan dalam kesatuan Pura Kahyangan Tiga yang terdiri dari Pura Desa, Pura Puseh dan Pura Dalem atau kuburan dimiliki bersama. Jalur prosesi ritual dari Catus Patha Denpasar ke Setra Badung dihubungkan oleh Puri Suci yang pada tiitk tengahnya ditempatkan sebuah pelinggih sebagai simbol kosmologis Kota Denpasar (Setiada, 2009).

\subsubsection{Periode zaman pemerintahan Kolonial Belanda di Denpasar}

Pemerintahan Kolonial Belanda di Denpasar diawali ketika seluruh pasukan Puri Denpasar termasuk Raja Denpasar saat itu yakni I Gusti Ngurah Made Agung gugur dalam Perang Puputan Badung pada tahun 1906. Semenjak saat itu, seluruh pemerintahan beralih ke tangan Pemerintah Kolonial Belanda. Tentunya pemerintahan Belanda memberi pengaruh yang signifikan terhadap penataan Kota Denpasar kala itu. Kawasan pusat kota mulai berubah, dimulai dari Puri Denpasar yang beralih fungsi menjadi Kantor Perwakilan Pemerintah Kolonial Belanda (Afdeeling Zuid Bali) dan sebagian dari bangunan Puri Denpasar difungsikan sebagai pemukiman para pejabat Belanda dan penginapan yang kini dikenal sebagai Bali Hotel. Ruang di sebelah selatan catus patha yang awalnya adalah pasar, berubah fungsi sebagai markas tentara Belanda dan lembaga peradilan (Raad Van Kertha). Kemudian untuk menunjang kegiatan ekonomi masyarakat Denpasar, Pasar Badung dipindah ke lokasi di Jalan Gajah Mada sekarang. Elemen yang tetap pada tempatnya pada masa ini adalah alun-alun yang dibiarkan oleh pemerintah kolonial Belanda menjadi ruang terbuka hijau kota di pusat kota. Ilustrasi keadaan Catus Patha Denpasar pada masa kolonial dapat dilihat pada Gambar 3. 


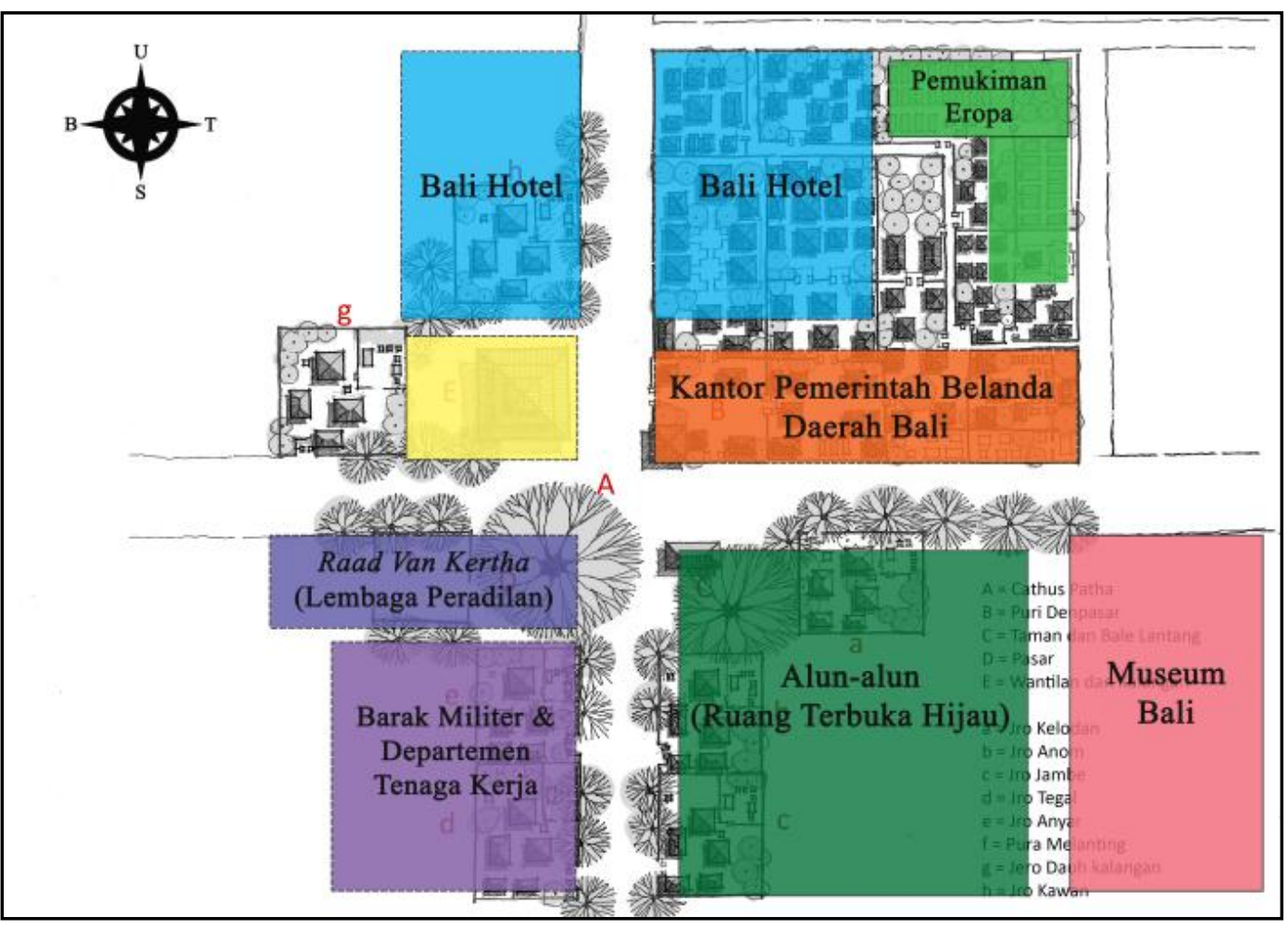

Gambar 3. Denah Catus Patha Denpasar pada Zaman Kolonial Belanda.

(Sumber: Data Penelitian Diolah, 2018)

Pengaruh politik Pemerintah Belanda terlihat juga pada struktur pola ruang permukiman di sekitar pusat pemerintahan. Hal ini ditunjukkan pada pemisahan antara permukiman orang-orang eropa dan penduduk asli yang menciptakan komposisi Kota Denpasar sebagai Kota Kolonial (Widiastuti, 2011). Perkembangan pola permukiman ini diikuti dengan pembangunan perumahan masyarakat pendatang dari Cina, Arab, dan India disepanjang koridor Catus Patha dari Jalan Gajah Mada saat ini hingga daerah Puri Pemecutan.

Pada periode ini catus patha yang memiliki pola paten sejak berabad-abad pada masa kerajaan di Bali mulai berubah sedikit demi sedikit. Walaupun tetap mempertahankan fungsi catus patha sebagai pusat negara, namun ada beberapa elemen yang tergantikan akibat pengaruh dari Belanda. Salah satu hal yang mendasari perubahan tersebut adalah dengan dibangunnya lonceng ditengah Catus Patha Denpasar atau elemen-elemen estetika yang berperan rangkap sebagai tanda pengenal orientasi. Hal ini secara langsung menunjukkan fungsi Catus Patha sebagai alat untuk "control of desire" secara halus dari Pemerintah Belanda terhadap masyarakat Denpasar, mengatur masyarakatnya dengan waktu modern, mengatur siklus hidup kota, serta menawarkan keteraturan dan kedisiplinan seperti halnya negara-negara di Eropa.

\subsubsection{Periode zaman setelah Indonesia merdeka}

Pada masa kemerdekaan Indonesia, Kota Denpasar mulai berbenah. Demikian pula yang terjadi pada Catus Patha Denpasar yang ikut mengalami perubahan pada elemen-elemennya. Seiring dengan perubahan kekuasaan serta sistem pemerintahan Kota Denpasar dari sebuah kota kerajaan menjadi kota seperti saat ini, berpengaruh pada keberadaan unsur-unsur Catus Patha Denpasar yang berdampak pada fungsi yang terwadahi Catus Patha Denpasar. Unsur-unsur Catus Patha Denpasar pada masa kerajaan telah tergantikan dengan bangunan Kantor Gubernur Bali (Kantor Jayasabha) yang kemudian berubah menjadi rumah jabatan Gubernur Bali pada tahun 1978, Kantor Walikota Denpasar, kantor perbankkan, pertokoan, hotel, kantor militer (Kodim/Komando Distrik Militer), Museum Bali, Pura Jagatnatha dan alun-alun dengan monumen Perang Puputan Badung. Selain perubahan pada unsur-unsur sekitar Catus Patha Denpasar, hal prinsip yang mengalami perubahan adalah ruang kosong pada pusat Catus Patha di masa kerajaan, saat ini ditambah dengan Patung Catur Muka sebagai ikon dari Kota Denpasar sebagai pengganti jam lonceng di masa kolonial. Ilustrasi denah keadaan Catus Patha Denpasar pada periode ini dapat dilihat pada Gambar 4 

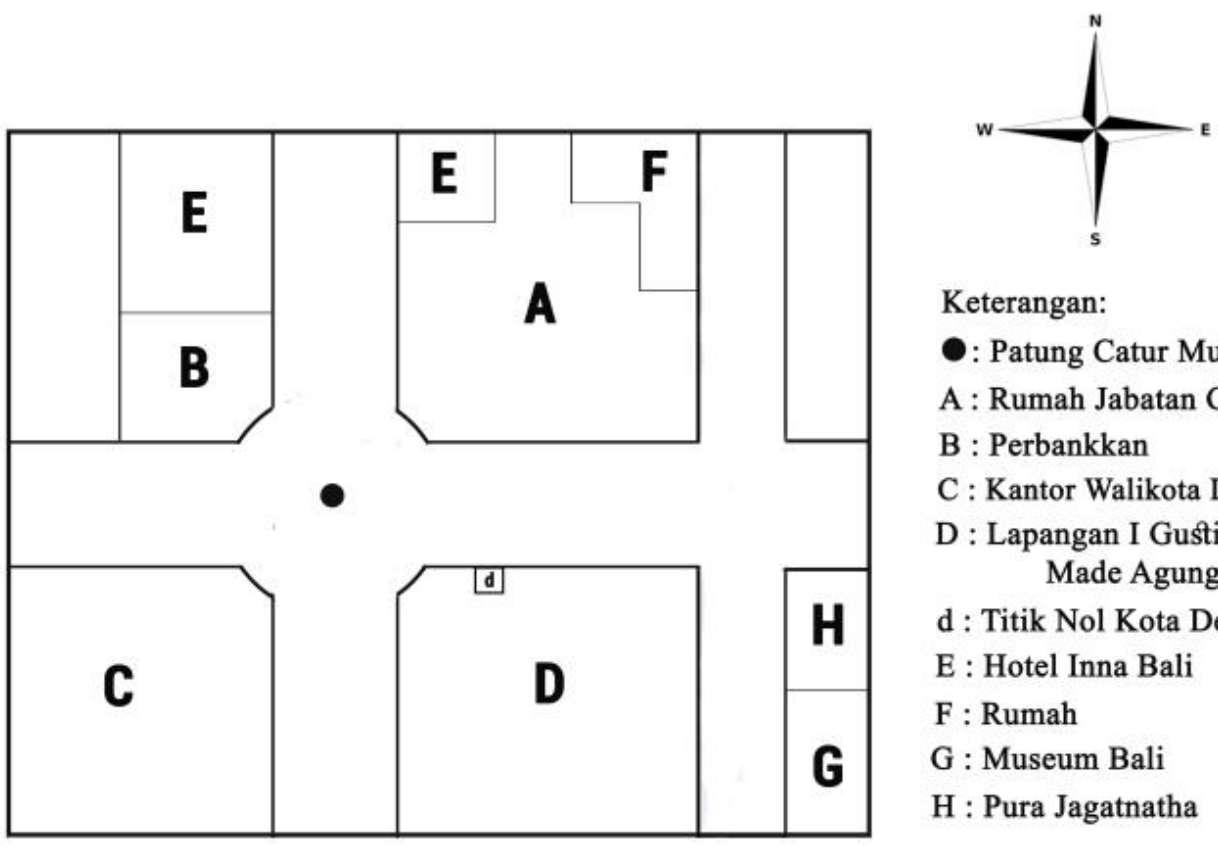

Keterangan:

- : Patung Catur Muka

A : Rumah Jabatan Gubernur

B : Perbankkan

C : Kantor Walikota Denpasar

D : Lapangan I Gusti Ngurah Made Agung

d : Titik Nol Kota Denpasar

E : Hotel Inna Bali

F : Rumah

G : Museum Bali

$\mathrm{H}$ : Pura Jagatnatha

Gambar 4. Denah Catus Patha Denpasar pada Periode Setelah Indonesia Merdeka

(Sumber: Data Penelitian Diolah, 2018)

Memasuki tahun 2000an Catus Patha Denpasar tetap memiliki fungsi utama sebagai pusat pemerintahan, walaupun bukan pusat pemerintahan provinsi. Hal ini ditunjukkan dengan keberadaan Kantor Walikota Denpasar yang menjadi simbol dari tempat untuk pelaksanaan pemerintahan. Perubahan elemenelemen ini disebabkan oleh pembangunan yang tidak terkendali dari pemerintah daerah dan jumlah penduduk yang mulai bertambah seiring dengan pertumbuhan Kota Denpasar. Pertumbuhan jumlah penduduk ini otomatis 'memaksa' kawasan Catus Patha berkembang menjadi kawasan permukiman campuran. Perubahan elemen-elemen dalam Catus Patha Denpasar berpengaruh dalam perubahan fungsinya sebagai pusat dan simbol kosmologis di Kota Denpasar.

Transformasi elemen yang terdapat di Catus Patha Denpasar tentunya berdampak pada fungsi awalnya sebagai pusat negara dan pusat kosmologi serta konsep awal catus patha yang membiarkan daerah bagian tengahnya kosong. Makna filosofi aktivitas ritual Hindu di Bali yang dilaksanakan pada Catus Patha Denpasar merupakan simbol dari proses penciptaan dan kehidupan yang berawal dari dan menuju ke alam sunya/kosong. Pada titik kosong tersebutlah ada pertemuan antara unsur purusa-pradhana atau langitbumi sehingga tercipta kehidupan di alam semesta ini yang terproses secara berulang-ulang dengan tujuan kembali pada kosong atau Tuhan sebagai Sang Tunggal (Atmaja 2003). Adanya unsur patung tentunya memiliki makna yang berbeda dengan konsep kosong, selain juga secara fisik perwujudan patung catur muka tidaklah sama dengan Tuhan. Secara fisik dapat dilihat bahwa patung catur muka menyebabkan terganggunya proses pertemuan langit dan bumi, sedangkan secara fisik patung yang mengambil wujud Dewa Brahma merupakan manifestasi Tuhan sebagai Siwa ke alam bwah loka (bumi) sebagai pencipta untuk menghubungkan manusia dengan Tuhan tidak sesuai (Atmaja 2003). Selain itu penempatan patung catur muka di tengah Catus Patha Denpasar menyebabkan terjadinya distorsi penempatan sarana dan pelaksanaan prosesi upacara keagamaan yang menggunakan media catuspatha bahkan dapat menggeser pelaksanaan kegiatan upacara tawur kesanga ke tempat lain seperti alun-alun atau catus patha yang baru. Padahal keberadaan patung tersebut merupakan upaya pemerintah dalam membentuk identitas/ciri khas Kota Denpasar. Hal tersebut sesuai dengan ide dari pembuatan patung lebih bersifat fisik sebagai titik fokus perhatian dan elemen estetika kota, bukan menjadi elemen fisik yang disakralkan (Putra, 2009). 


\section{Penutup \\ 4.1 Simpulan}

Perkembangan catus patha di Denpasar diawali dengan penggunaan konsep ini oleh Puri Denpasar sebagai pusat negara Badung. Penerapan konsep catus patha pada masa kerajaan dapat dikatakan sebagai penerapan yang paling taat dan disiplin dibandingkan dengan masa-masa selanjutnya. Pada masa kerajaan nilai-nilai filosofis serta fungsinya masih pada konsep awalnya. Memasuki zaman kolonial Belanda, fungsi Catus Patha Denpasar sebagai pusat negara masih dipertahankan, namun tentunya dengan akulturasi budaya yang dibawa dari Belanda. Selanjutnya memasuki masa kemerdekaan Indonesia, perubahan yang dialami Catus Patha juga terletak pada elemen-elemennya yang juga mempengaruhi fungsinya. Fungsi catus patha sebagai pusat negara hanya dicerminkan melalui letak Kantor Walikota Denpasar yang merupakan tempat menjalankan roda pemerintahan tingkat kota. Banyaknya permukiman campuran serta dibangunnya patung catur muka menunjukkan bahwa terjadinya proses transformasi fungsi pada Catus Patha Kota Denpasar. Maka dari itu, berdasarkan fenomena tersebut, saat ini fungsi sosial ekonomi dan permukiman campuran justru lebih mendominasi fungsi Catus Patha Denpasar karena keberadaan bangunan kantor perbankkan, pertokoan, hotel dan rumah penduduk di sekitar catuspatha, sedangkan fungsi sebagai pusat pemerintahan kota yang seharusnya menjadi fungsi utama Catus Patha hanya terwakilkan pada unsur kantor walikota Denpasar yang ada di sudut barat daya Catus Patha Denpasar.

\subsection{Saran}

Berdasarkan simpulan diatas, penulis menyarankan untuk perlu adanya peningkatan pemahaman akan konsep Catus Patha khususnya pada pemerintah, sehingga kebijakan-kebijakan yang lahir terkait dengan upaya pengamanan Catus Patha Denpasar tidak terlepas dari konsep yang ada, namun tetap sejalan dengan perkembangan kota. Begitu pula halnya dengan keberadaan fungsi-fungsi pada Catus Patha Denpasar, khususnya fungsi ritual/upacara Hindu yang dikembalikan pada kesesuaian konsep catus patha. Penulis juga menyarankan agar dilakukan penelitian lanjutan mengenai dampak dan solusi yang ditimbulkan akibat dari perubahan fungsi catus patha dari segi sosial dan budaya baik di masa kini ataupun bagaimana dampaknya di masa yang mendatang.

\section{Daftar Pustaka}

Atmaja, J. (2003). Perempatan Agung: Menguak Konsepsi Palemahan, Ruang dan Waktu Masyarakat Bali. Denpasar: Bali Media Adhikarsa.

Dharma, I. dan I. Weko (2017). Pengaruh Konsep Catus Patha Terhadap Tata Ruang Pemukiman di Kawasan Transmigrasi Masyarakat Bali. Denpasar, Seminar Nasional Arsitektur dan Tata Ruang (SAMARTA) Bali.

Goodchild, P. (1990). Some Priciples for the Conservation of Historic Landscape. London: ICOMOS (UK) Historic Gardens and Landscape Comittee.

Mahira, E. (2014). Persepsi Masyarakat Tentang Fungsi Kekinian Catuspatha Denpasar. Ruang-Space: Jurnal Lingkungan Binaan. Vol. 1 No. 2, pp. 192-204.

Munandar, A. ( 2011). Catuspatha: Arkeologi Majapahit. 1st ed. Jakarta Selatan: Penerbit Wedatama Widya Sastra.

Nurisjah, S. dan Q. Pramukanto. (2001). Perencanaan Kawasan untuk Pelestarian Lanskap dan Taman Sejarah.. Bogor: Institut Pertanian Bogor, Fakultas Pertanian, Jurusan Budidaya Pertanian, Program Studi Arsitektur Lanskap.

Putra, G. (2018). Defining and Sustaining The Place Identity of A Traditional Yet Rapidly Developing City (The Case of Denpasar - Bali, Indonesia, Oxford: PhD Thesis Oxford Brookes University.

Putra, I. (2009). Perubahan Ekspresi Catus Patha dalam Tata Ruang Pusat Pemerintahan di Kota Denpasar. Perspektif Kajian Budaya, Denpasar: Universitas Udayana.

Setiada, N. (2009). Penelusuran Sejarah Kota Denpasar. Denpasar: CV. Cipta.

Simonds, J. (1983). Architecture: A Manual of Site Planning and Design. New York: McGraw-HillBook Company.

Widiastuti (2011). Konservasi Kota Denpasar: Harapan dan Kenyataan. Jurnal Permukiman Natah, Vol. 9 No.1, pp. 10-25.

Yudantini, M. \& David, J., 2015. The Catuspatha Pattern in Balinese Palace Architectural. Procedia Environmental Sciences. Volume 28, pp. 538-548. 